Original paper

\title{
Comparison of volcanic threat challenges in Iceland and Japan
}

\author{
Ásthildur Elva Bernhardsdóttir ${ }^{1 "}$, Jónas Elíasson ${ }^{1}$
}

Received: 30/11/2017 / Accepted: 19/11/2018 / Published online: 25/07/2019

\begin{abstract}
The authorities in Iceland and Japan face various challenges in their efforts to reduce risks of volcano disasters. While Japanese society is much older and has therefore longer experience of facing those challenges the current methods and strategies of both in planning, monitoring, preparedness, relief, and recovery operations are similar. The aim of this paper is to show how these similarities create opportunities for knowledge transfer between Iceland and Japan in disaster prevention methods utilized in meeting volcanic risks, with due concern of the weaknesses, management methods can show when transferred to an entirely different cultural environment.
\end{abstract}

Both nations use modern scientific technologies for risk assessment and disaster management but several geological-, situational-, infrastructural- and cultural differences between the countries and differences in the practice of cooperation with scientists in disaster prevention make different tactics necessary. While both countries lie on the boundary of large tectonic plates, in Iceland the plates are diverging with heavy rifting and volcanic outbreaks in unexpected places while Japan lies along a subduction zone with tectonic events of large magnitude. Iceland has dangerous glacial floods of volcanic origin while the greatest flood hazard in Japan comes from the sea in form of tsunamis. Japan is more densely populated than Iceland, but both are developed countries where large sums of public funds are diverted into disaster prevention and recovery. There are similarities in such fields as monitoring of volcanic eruption and in the problem structure of tourist safety and other fields where cooperation between Japan and Iceland can produce results. Icelandic and Japanese scientists have achieved good results in the field of assessing the danger of volcanic ash plumes for the civil aviation and Japan is now presenting improved methods in ash cloud forecasting in the international community. It is concluded that closer cooperation has good potential to bring about further results because of similar challenges posed by the volcanic environments of both countries. While it has been determined that disaster management structures are similar, cultural differences in hierarchy and egalitarianism have their effects on information methods and use of volunteer rescue organizations. Cooperation between Universities has brought academic results but further academic and practical results could come from cooperation between

${ }^{1}$ University of Iceland, Earthquake Engineering Research Center, Austurvegur 2a, Selfoss, Iceland.

* Corresponding author: aeb@hi.is 
townships in the two countries. In such work it is essential that the civil protection authorities understand and identify the influence of culture on disaster prevention and preparedness. Both societies' experiences of long periods of isolation have, among other things, resulted in rather homogenous and self-reliant cultures that have influenced the way in which they have managed disasters. Dominant cultural values as well as competing values need to be considered in order to reduce disaster risk and strengthen societal resilience.

Key words Volcanic activity; Earthquake risk; Disaster management; Cultural influence.

\section{INTRODUCTION}

In case of volcano disaster-risk, civil authorities are dependent on the guidance of scientists monitoring active volcanoes with geophysical instruments (Kuswandarto et al. 2008; Iguchi et al. 2008; Nishimura et al. 2012). From this data eruptions are predicted (Ishihara et al. 2011; Roberts et al. 2011), appropriate warnings issued, (Kamo 1989), and risk and hazard assessments provided to the civil protection service, (Hendrasto et al. 2012; Neri et al. 2008).

The differences in the physical environment are a great challenge in this respect. The earth's volcanism is largely confined to the tectonic plate boundaries. In Japan the plates are drifting together and very strong earthquakes, up to magnitude 9,1 occur in the extensive subduction zones that parallel the east coast of Japan. The most powerful earthquake ever recorded to have hit Japan, the Tohoku earthquake that occurred 14:46 JST (05:46 UTC) on Friday 11 March 2011 (Suzuki et al. 2012), was particularly devastating. This earthquake and the subsequent tsunami (2011 Tōhoku earthquake and tsunami) caused extensive property damage, US\$235 billion according to the estimate of the World Bank. The area suffered around 20.000 casualties and 100.000 children were uprooted from their homes. The Japanese Government aims to finish the reconstruction of Tohoku before the end of 2020. Most of the infrastructure in the affected area has been recovered but housing reconstruction is ongoing (Prime Minister of Japan and His Cabinet 2016).

In Iceland the plates are drifting apart, see e.g. Thordarson, and Larsen (2007). This causes one of the principal stresses in the earth's crust to become tension stress so rifting is very common at the plate boundaries. Consequently, intrusion activity, (Elíasson 2013), is high, earthquakes frequent and volcanic eruptions can pop up almost everywhere and anytime, inside the volcanic zones associated with the plate boundaries, new and old. A recent example is the Holuhraun eruption. Nevertheless it is possible to identify four major regions and do risk assessments for each (Elíasson 2014). Earthquakes are more frequent in Iceland than in Japan but not as strong - earthquakes larger than $7 \mathrm{MW}$ have not been recorded. Unlike the subduction zones of Japan, Icelandic earthquakes resulting from rifting do not generate tsunamis (Elíasson and Sigbjornsson 2008 and 2013).

Iceland has not, in recent history, suffered casualties due to volcanic eruptions or earthquakes, nevertheless they are life threatening events that are closely monitored and are the main concern of the civil protection authorities. This is especially due to the sudden and violent glacial floods, jökulhlaups, triggered by subglacial volcanoes. Several of those are situated inside Myrdalsjökull and Vatnajökull close to the points where the plate boundary takes a $45^{\circ}$ turn.

In Japan the volcanoes and their craters are well known and the most dangerous ones are monitored by special volcanological observatories utilizing almost all available geophysical technology in their work (Yokoo et al. 2014). 
Operating principles of the Icelandic civil defense system are formed very much according the Scandinavian tradition. The Scandinavian nations are of same origin with similar cultures, thus methods and experiences are easily transferred between any of the Scandinavian nations. Geophysically, however, Iceland is very different from Scandinavia but shares many of the geophysical disaster risks of Japan.

The aim of this paper is to analyze the opportunities for knowledge transfer between Iceland and Japan in disaster prevention methods utilized in meeting volcanic risks. In the same time discuss the weaknesses management methods can show when transferred to an entirely different cultural environment. Sources for this paper are both technical and social science studies as well as governmental reports of historic events. The technical studies include probabilistic studies of volcanic eruption risks in Iceland (Elíasson 2014b), airborne measurement campaigns of volcanic ash clouds (Webster et al. 2012; Weber et al. 2012) and tsunami propagation studies in Japan and Iceland. The social science studies include case studies on disaster management in Iceland and Japan as well as literature on disaster management. The governmental reports are on historical disasters, disaster management and the disaster management systems within the two countries. The cultural discussion is based on a study on how culture influences crisis management and studies that report on measurements of cultural dimensions within Iceland and Japan societies. In Chapter 1, technical studies are underlying in the discussion on the physical environment and the natural risk as to the scientific effort to understand and cope with the risk. The social science perspective is brought forward in Chapter 2 where the focus is on the historical, institutional and cultural context. Chapter 3 provides discussion on lessons on volcanology and disasters caused by eruptions with special focus on the opportunities to transfer knowledge between the two countries. Finally, the conclusions of this study is summarized in Chapter 4.

\section{Natural disaster risk}

Without explaining the general concept of Volcanic risk (see e. g. the recent 408-page book, Loughlin et al. 2015 for geology, risk factors, and examples), it is sufficient to state that the general risk factors in Iceland and Japan also involve earthquakes, high winds (typhoons in Japan), floods, avalanches, drought and sea level rise. In the list of countries ranked by natural disaster risk in the World risk index (World Risk Report 2016), Iceland ranks sixth and Japan ranks $155^{\text {th }}$ out of 173 countries. Iceland is thus very low, Japan very high. Never the less, natural disasters are more frequent in Iceland, but in the more densely populated Japan, fatalities are more common, e.g. due to the violent earthquakes $\mathbf{M}_{w} 7-9.1$ and associated tsunamis in Japan.

A great variety of risk information on volcanoes is issued in Japan, e.g. NIED 2013. Fig. 1 is from that publication, and it works through Google Earth. 


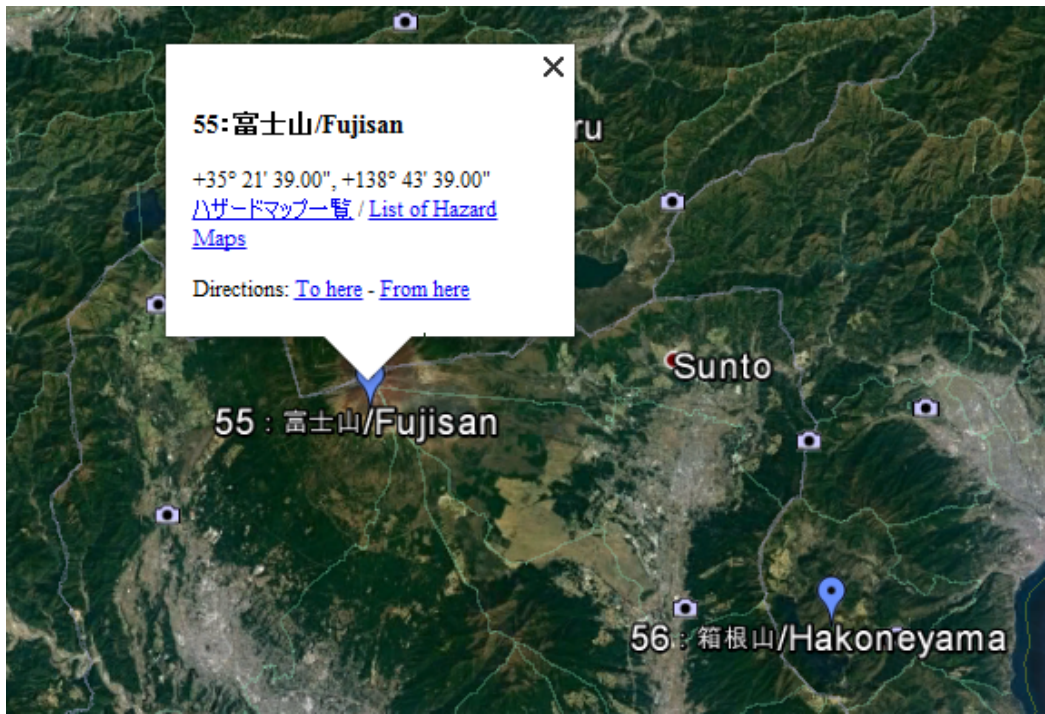

Figure 1. Information on Fujiyama Volcano Japan, NIED 2013

Extensive research has been done on volcanic risk in Iceland. In Japan the craters can be pinpointed, but in Iceland it is difficult to do, but certain regions can be identified (Elíasson 2014b Fig. 7).

In Iceland the PEI (Population Exposure Index) ranges from low at PEI 2 to high at 5. With most volcanoes classed at PEI 2, the majority of Icelandic classified volcanoes are classed at Risk Level I, but four being Risk Level II (Brown et al. 2015). In the same publication number of historical volcanic eruptions larger than VEI 4 (Volcanic Explosion Index) are found similar in Icelandic and Japan regions (22 and 25).

Five percent of all tsunamis are triggered by volcanoes. A known Japanese tsunami of that nature is the 1780 eruption in Sakurajima Volcano when an underwater explosion generated six-meter-high wave. Debris avalanches formed from collapsing volcanic slopes can also create tsunamis. Five Japanese cases are known since early 1640s with one of which the 1792 eruption of Unzen Volcano in Kyushu that generated a tsunami up to 55 meter. In 1693, Iceland's Mt. Hekla produced a tsunami (Walker and Bellingham 2011).

Iceland and Japan are among eight countries that have volcanoes with relatively large ice masses. The most famous are Katla in Iceland and Fujisan in Japan (Fig. 1). Glacial outburst floods or jökulhlaup can cause tsunami such as the 1918 flood from Katla that produced 1-5 meters tall tsunami that reached the offshore Vestmanna Islands. In Iceland jökulhlaups are the most common hazard related to volcanism and are very dangerous due to how enormous and unique they are (Elíasson et al. 2007). Jökulhlaups are an exceptional class of extreme rare natural hazard events which pose a critical evacuation dilemma for civil protection officials, especially the volcanoes in Mýrdalsjökull. To define the evacuation area, numerical simulations of the floods are prepared (Elíasson 2014b Fig. 7). However, there is a great need for reassessing these simulation runs, especially the initial conditions. The glacier is much thinner today and hydrodynamic model laws indicate that peak flows vary with the thickness to the second power. If this is true, the danger in nearby population centers can be much less than indicated by the older simulations.

The probabilities of eruption in the Mýrdalsjökull vents is estimated in Elíasson et al. 2006. Reassessment of the probabilities is in Elíasson 2014b, but the same database is being used. New simulations using all available new data (Óladóttir et al. 2014), could be necessary 
here also, as it is found that the probabilities for an eruption with consequences overshadowing the 2010 Eyjafjallajökull eruption seem quite high (Elíasson 2014b). This is especially dangerous as there are no indications that the shortcomings of the ash cloud forecasts experienced in the North Atlantic 2010 and the Grimsvötn eruption 2011 have been overcome.

Predictions of volcanic eruptions in Iceland remain primarily supported by earthquake data. However, forecasts by deterministic methods have very limited success. This makes probabilistic methods more valuable, they are a valuable indication of where to allocate available funds for preparations. E.g. stochastic model for the Bardarbunga system might be possible from existing data in Larsen and Gudmundsson 2014.

Because jökulhlaups are more easily predicted than, say earthquakes, it is easier to manage the risks involved and to evacuate the population - though not, as is clear from the Grimsvötn experience, mitigate the risk to infrastructure.

\section{HISTORICAL, INSTITUTIONAL AND CULTURAL CONTEXT}

The islands of Japan are not only geologically much older than Iceland but so too is Japanese society that had their first migrants in prehistoric time while Iceland was settled in late 9th century. Between the years $1000-800 \mathrm{BC}$ (the Yayoi period) social stratification began developing in Japan and thus giving way to the social elites who governed through centuries (Jinam et al. 2015). When Iceland had just been settled and its government in its infancy, Japan was united under a centralized government, nominally controlled by the Japanese Emperor. From the settlement in Iceland, through Norwegian rule to Danish rule to the Republic of Iceland the isolation of the country was rather persistent (Thorsteinsson and Jónsson 1991).

Climate shifts unfavorable to farming, disasters, and plagues resulted in hardship for Icelanders and increased their isolation. Like Iceland, the Japanese Islands have been largely isolated until modern times due largely to governmental policies. The Tokugawa shogunate that governed through the Edo period (1600-1868) cut all contact with the outside world, for example (Encyclopedia Britannica).

Hence, both Japanese and Icelandic societies have, throughout their histories, experienced long periods of isolation that resulted, among other things, in rather homogenous and selfreliant cultures.

\subsection{Disaster management: structure and functions.}

Japanese society has, through centuries, tried to deal with disasters in an organized fashion with the resources available at the time of disaster. The oldest manual found is for instance from late 1700's, and included guidelines on evacuation procedures in case of an eruption of Mount Unzen (Japanese Times, 1991.06.05)

The modern legal framework for managing disasters on a national basis was established in Japan in 1961 and the first civil defense legislation in Iceland that covers assistance during natural catastrophes dates back to 1967 . Thus, the modern systems were created in the 1960ies in both countries and are similar in many ways - but yet have some different nuances.

On the national level in Japan, the Basic Disaster Management Plan is formulated and promoted, which is a comprehensive and long-term disaster management plan forming a foundation for the Disaster Management Operations Plan and Local Disaster Management Plan 
(See Fig 2a). It covers provisions for the establishment of the system, promotion of disaster management measures, post-disaster recovery and reconstruction.

\begin{tabular}{|c|c|c|}
\hline National level & $\begin{array}{l}\text { Prime Minister } \\
\text { Central Disaster Management } \\
\text { Council } \\
\text { 1) Designated Gov. } \\
\text { Organizations } \\
\text { 2) Designated Public } \\
\text { Corporations }\end{array}$ & $\begin{array}{l}\text { Formulation and promoting implementation of } \\
\text { the Basic Disaster Management Plan } \\
\text { Formulation and implementation of the Disaster } \\
\text { Management Operation Plan }\end{array}$ \\
\hline $\begin{array}{l}\text { Prefectural } \\
\text { level }\end{array}$ & $\begin{array}{l}\text { Governor } \\
\text { Prefectural Disaster } \\
\text { Management Council } \\
\text { Designated Local Government } \\
\text { Organization } \\
\text { Designated Local Public } \\
\text { Corporations }\end{array}$ & $\begin{array}{l}\text { Formulation and promoting implementation of } \\
\text { Prefectural Disaster Management Plan }\end{array}$ \\
\hline $\begin{array}{l}\text { Municipal } \\
\text { level }\end{array}$ & $\begin{array}{l}\text { Mayors of Cities, Town and } \\
\text { Villages } \\
\text { Municipal Disaster } \\
\text { Management Council }\end{array}$ & $\begin{array}{l}\text { Formulation and promoting implementation of } \\
\text { Municipal Disaster Management Plan }\end{array}$ \\
\hline $\begin{array}{l}\text { Residents } \\
\text { Level }\end{array}$ & Residents and Enterprises & $\begin{array}{l}\text { Formulation and promoting implementation of } \\
\text { Community Disaster Management Plan }\end{array}$ \\
\hline
\end{tabular}

Figure 2a. Disaster Management in Japan. Outline of the system. (Cabinet Office 2015)

The Central Disaster Management council consists of the Prime Minister as the chairperson, all members of the Cabinet, head of major public corporations and experts (See Fig 2b). The council develops the Basic disaster management policies and plays a role of promoting comprehensive disaster countermeasures including deliberating important issues on disaster management upon requests from the Prime Minister or Minister of State for Disaster Management.

The Prime Minister with the Council, designated governmental organizations, and public corporations, formulate and promote the Basic Disaster Management Plan which the organizations and corporations implement. 


\begin{tabular}{|l|l|}
\hline Chair & $\begin{array}{l}\text { Prime Minister } \\
\text { Minister of State for Disaster Management } \\
\text { and all members of the Cabinet }\end{array}$ \\
\hline Members & $\begin{array}{l}\text { Heads of Designated Public Corporations } \\
\text { Experts } \\
\text { Committees for technical investigation }\end{array}$ \\
\hline Disaster Management Implementation Committee \\
\hline Chair & \multicolumn{1}{|c|}{ Officers Meeting } \\
\hline $\begin{array}{l}\text { Advisor } \\
\text { Vice- } \\
\text { Chair }\end{array}$ & $\begin{array}{l}\text { Deputy Chief Cabinet Secretary for Crisis Management } \\
\text { Director General for Disaster Management Cabinet Office. }\end{array}$ \\
\hline
\end{tabular}

Figure 2b. Disaster Management in Japan. Outline of the system. (Cabinet Office 2015)

An example of what the Japanese system has prepared is the recovery plan and operations in the aftermath of the huge disaster, the Tohoku earthquake and tsunami 2011 mentioned in the introduction.

The system in Iceland operates under the Ministry of Justice with its command structure arranged through the office of the National Commissioner of the Police (see Fig 3a). Planning of preparedness is done in close cooperation with the local chiefs of police that oversee commanders and coordinators in the field This work is by police authority in both countries.

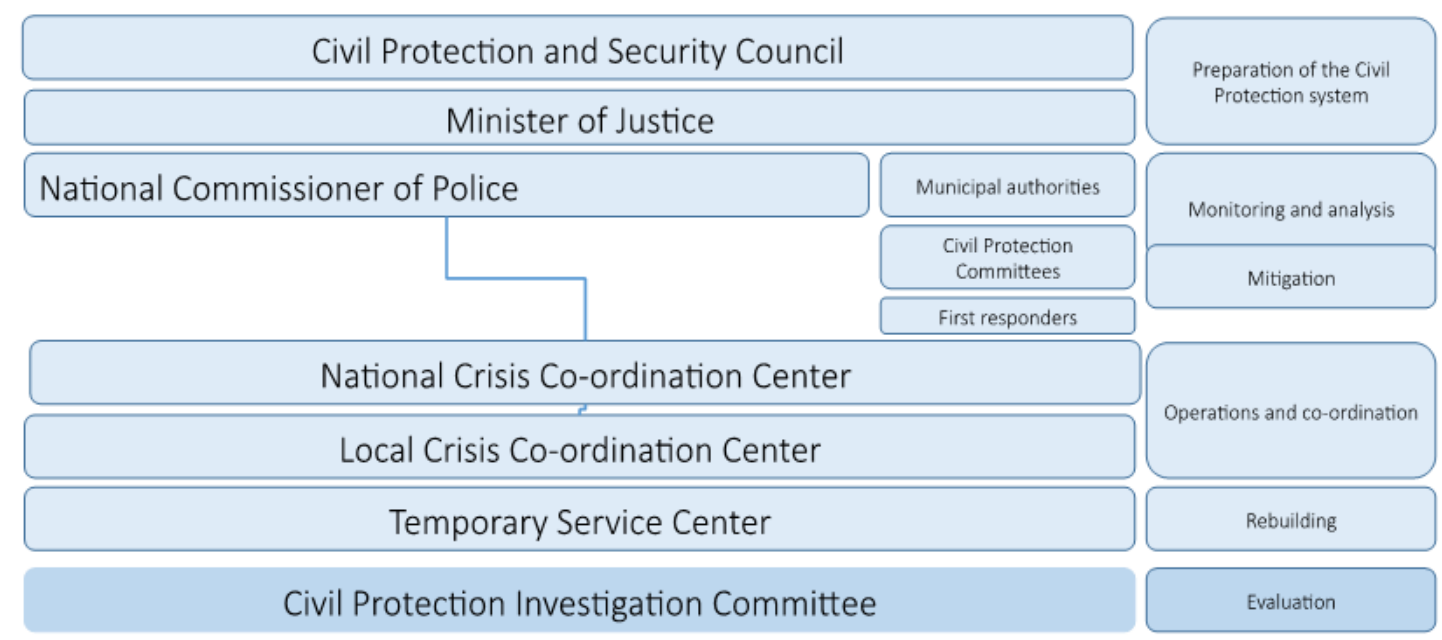

Figure 3a. The civil protection system in Iceland. Outline of the system. (Civil Protection Authority).

In the Civil Protection and Security Council sits the Prime Minister who shall also be chairman of the council, other ministers, permanent secretaries of ministries and representatives of Icelandic Organization for Search and Rescue (ICE-SAR), the Icelandic Red Cross, and the coordinated emergency telephone answering system (see Figure $3 b$ ). 


\begin{tabular}{|l|l|}
\hline Chairman & $\begin{array}{l}\text { Prime Minister } \\
\text { Minister of Justice and Ecclesiastical Affairs }\end{array}$ \\
\hline $\begin{array}{l}\text { Minister of Transport and Telecommunications } \\
\text { Minister for the Environment } \\
\text { Minister of Health } \\
\text { Minister for Foreign Affairs } \\
\text { Minister of Industry }\end{array}$ \\
\hline $\begin{array}{l}\text { Permanent Secretaries at the above mentioned ministries } \\
\text { Heads of Designated Gov. Org. and Public Corporations }\end{array}$ \\
\hline Representatives of & $\begin{array}{l}\text { ICE-SAR (Slysavarnafélagid Landsbjörg) } \\
\text { The Icelandic Red Cross } \\
\text { The coordinated emergency telephone answering system }\end{array}$ \\
\hline
\end{tabular}

Figure 3b. The civil protection system in Iceland. Organization of Civil Protection and Security Council (Civil Protection Authority).

An example of what this system has prepared is a comprehensive plan for mitigation in case of a Katla eruption. There are several stages in the plan (Department of Civil Protection and Emergency Management).

\subsection{The influence of culture on disaster management in the two countries}

Disaster management covers prevention/preparedness, response, and relief and reconstruction. In disasters, decision-makers' belief that important values are threatened which demands imminent response to a situation of great uncertainty. Thus, decision-makers' values are being tested while they display their capability to face challenges in ways their culture demand of them (Thompson et al. 1990; Bernhardsdóttir 2015a)

Measurement of cultural dimensions in Iceland and relative comparison with 25 OECD countries show that in Japan, power distance, uncertainty avoidance and longtime orientation is emphasized relatively more than in Iceland (Gudmundsdóttir et al. 2015). Power distance displays the degree to which people are comfortable with influencing upwards, how accepting they are of inequality in distribution of power. Uncertainty avoidance displays people's level of comfort with change versus a preference for the known. It does not equal risk avoidance, rather acceptance that necessary measures need to be made to avoid uncertainty in order to accommodate risk. Long-term orientation reflects the long-term vs. short-term perspective (Hofstede and Hofstede 2005; Bernhardsdóttir 2015a) Thus, the propositions can be made that Japan disaster management relies more (than Iceland) on centralized processes, belief in the need and ability to avoid uncertainty, and planning for the future.

Grid-group cultural theory offers four cultural types exposed in two fundamental dimensions of social life: boundedness/collectivity and prescription/stratification. Hierarchy scores high on both stratification and collectivity; egalitarianism score low on stratification but high on collectivity; individualism scores low on both stratification and collectivity; and fatalism scores high on stratification but low on collectivity. These cultural types are always present in every group and are in constant state of tension with each other. Both hierarchy and egalitarianism share emphasis on collectivity and reflect decision-makers with belief in the need and ability to avoid uncertainty i.e. that measures should be taken to prevent and/or prepare for disasters

In Japan, hierarchy has been respected for centuries, thus the stress on high power distance 
or high stratification should not be surprising. A study on culture and crisis management in Iceland (Bernhardsdóttir and Kristinsson 2003) concludes that egalitarianism is most dominant and reflected in the way in which Icelanders manage crises. Hence, both in Iceland and Japan, the culture should believe in the need and ability to prevent and/or prepare for disasters. Disaster management in Japan is expected to emphasize centralized decision-making with strong reliance on expertise, which are typical characteristics of hierarchy. In Iceland decentralized decision-making is emphasized, with an unclear division of responsibility and tasks, and hesitancy in leaving it to the experts to pave the processes, which are typical characteristics of egalitarianism. According to a theoretical definition, a structure of decentralized administration belongs to the so called "coordination model," which constitutes a decentralized system. The concept behind such a model is, among other things, that the decentralized administrative units are present when solving a problem, but they do not constitute a hindrance. An emergency situation requires both a decentralized and a complicated decision-making process; therefore rather than trying to apply a centralized decision-making process to solve the problem, the decisions made by the independent decision-makers should be supported (Rosenthal and Kouzmin 1993).

Centralization of decision-making as bureaucratic response to crisis has been recognized over decades. Crisis triggers contraction of authority, and as a result of the increased stress, the existing authority then tries to pass the burden on to the next management level above (Hermann 1963; 't Hart, 1993). Taking culture into account, high grid cultures show stronger tendencies toward contraction of authority than the low grid cultures. Research on the influence of culture on crisis management shows that while contraction of authority happens quite frequently in crisis response, low grid decision units show decentralization more often than do high grid decision units, i.e. in 52 percent of crisis-cases compared to 25.6 percent (Bernhardsdóttir 2015a). The difference in disaster management between Iceland and Japan reflects these findings.

It is difficult, and time consuming to gather information and coordinate the task within a decentralized structure. The hierarchical Japanese information-system is the more detailed than the Icelandic system with shorter response time and quicker updating of online information. Research on disasters in Iceland such as avalanches and earthquakes display lack of awareness for the important role information gathering plays in crisis preparedness (Bernhardsdottir and Svedin 2004).

In the Japanese system, authorities and experts are officially given more influential roles than in the Icelandic system. As displayed in the Japanese chart of Organization of Central Disaster Management Council (Figure 2b) experts are included in the council and thus offer opinions and work on reports delivered to the Prime Minister and the Minister of State for Disaster Management. In Iceland, disaster management on national level is one of the many responsibilities of the Minister of Justice and experts are not included in the official chart. Before 2003 the civil defense agency in Iceland was directly under the council with the director of the council also being the director of the agency. Thus, it reported directly to the minister of justice. Currently, as shown above, the National Commissioner of Police comes in between the Minister of Justice and the agency. Thus, it can be argued that there has been a slight hierarchical shift in the highest level of administration governing disaster management. Such a shift is not noticeable in the rest of the system.

In Japan, the Self-Defense Forces (SDF) are given the authority to respond and operate in emergency situations when officially requested. An important step towards strengthening crisis management planning in the country is how the reluctance to use the forces, in crisis response situations, has been eased over the last decades. There is now a broad public support in the 
Japanese society for the disaster relief missions of SDF that are in general based on three principles: contribution to common good, urgency, and the absence of comparable civilian alternatives (Yoshizaki 2012). Iceland has no army, which makes the strength of the volunteer organizations such as rescue teams and the Icelandic Red Cross organizations of paramount importance for the nation when an emergency situation arises.

In order to compare the way in which Japanese and Icelandic people managed volcanic disasters in historic times the year 1783 is of special interest. That year, both Iceland and Japan suffered large volcanic eruptions with devastating consequences where crops were poisoned, and people and livestock starved to death. The Tenmei Asama eruption began $9^{\text {th }}$ of April and two months later on the $8^{\text {in }}$ of June the craters of Laki began erupting (Disaster Management, Cabinet Office 2006; Klemetti 2013). The relief and reconstruction processes in the aftermath bore witness of very different societies. Japan already had a structured society with defined privileges and responsibilities, while Iceland was governed from Denmark with no strategy to rely on in times of disasters and information processing between Iceland and Denmark being extremely slow. The eruption and its consequences claimed about fifth of the Icelandic population. Reykjavik was just a village and local officials were spread around the country but even between them there was no co-ordination when it came to deal with the famine and sharing of the fish. Even more food was being exported than imported during this time of starvation among Icelanders (Karlsson 2010) This grave disaster rekindled the old belief that disasters were the act of God as a punishment for the sins of man. This belief and its notion of powerlessness extruded people into apathy and thus fatalistic culture became dominant in the long period of relief and recovery. In Japan the task of the shogunate was the executive role. He kept overview and helped with restoration, requested the transportation network to be rebuilt, gave orders to the clan lords to clean up villages and provide nutrition to the starving population etc. (Disaster Management, Cabinet Office 2006).

The strict classification gap-i.e. the high-power distances - in Japanese society has through the time caused problems in disaster management but examples from the response to Tenmei Asama eruption also show how it was overstepped in reconstruction of communities. In the Kamahara village that was badly affected by the eruption, structures were not only rebuilt but so also were families. Victims were paired together without regard of different status of families they belonged to. Hence, widows were married to widowers and they adopted children who had lost their parents etc. These family reconstructions were not driven by the survivors' voluntary intention but promoted by leading farmers in the area (Disaster Management, Cabinet Office 2006). Thus, although barriers were broken between the victims it shows how people were accepting measures/policies made by higher-status individuals in order to reconstruct communities'-measures that were affecting their personal lives at its inner core.

The volcanic eruption in Heimaey1973 that led to evacuation of the inhabitants convinced Icelanders of the necessity to establish a relief fund to support and rebuild communities after such a grave disaster. The Iceland Catastrophe Insurance was founded in 1975 and functions as an insurance company. All buildings are insured against natural perils covered by the program (Iceland Catastrophe Insurance). The phase of relief and reconstruction of communities was included in a new legislation on civil protection in year 2008 (Civil Protection Act No. 82 June 2008). The same year local governments were offered guidelines for long-term recovery based on cooperative work between university experts and other specialist in the field on disaster management as well civil protection authorities at national and local levels. Several local governments have made local plans based on the guidelines. In Japan the Prime Minister's National Relief Fund accepts voluntary contributions, which are exempt from income tax. Several other voluntary relief-funds for victims of disasters in Japan 
can be found. In Iceland relief funds have be launched for disaster victims such as for the communities hit by grave avalanches in 1995 .

\subsubsection{Voluntarism}

Voluntarism is citizens' participation at its finest and comes closest to reflecting the egalitarian culture. The Icelandic Civil Protection Agency has an agreement with the volunteer organizations regarding their responsibility for rescue missions, taking care of mass social assistance, clearing services, and providing first aid. The general level of preparation in Japan has been on the national level but established bodies and procedures for response at the local level. The voluntarism in Iceland reaches the national level and thus is also important in preparation for disasters. Scientific organizations and scientists were called upon to both lead and assist the construction of the civil defense system, which they did on a voluntary basis. Thus, the scientific contribution reflects the emphasis on participation. It is noted that the expertise relied upon is on the technical part of disaster management. The fact that volunteer organizations have representatives in the civil protection council and a formal agreement with the civil protection agency reflects its important role and status in the civil protection system in Iceland.

Japan

- On the rise

- Role of voluntary organizations in response and recovery strengthened in the aftermath of 1995 Kobe earthquake

- 1998: law to promote nonprofit activities

- 2011: GEE pushed for wider recognition - role in disaster prevention

- 2013: Disaster Countermeasure Basic Act stating that both national and local authorities shall partner with civil organizations

\section{Iceland}

- 1962/1967: Important from the beginning of the construction of the CD system.

- Scientific organizations and scientist called upon to both lead and assist the construction of the civil defense system on voluntary base (technical part of DM).Regular meetings.

- 1974: first agreement. CPA has an agreement with the volunteer organization (ICE-SAR, IRC) regarding their responsibility for rescue missions, mass, social assistance, clearing service, and providing first aid

Figure 4. Role of voluntarism in emergency response and relief in Japan and Iceland

Voluntarism is also important in Japan and has been on the rise over the last two decades. After experiencing the two grave disasters in Japan, the 1995 Kobe earthquake and the Great East Earthquake (GEE) in 2011 the quest has been to strengthen profoundly the role of civil society organizations in disaster management. The contribution of voluntary organizations in response and recovery in the aftermath of 1995 Kobe earthquake led to the official recognition by the government that enacted law to promote specified nonprofit activities in 1998. The vital role they played in the 2011 GEE disaster pushed the government to widen this recognition by giving them role in disaster prevention. The Disaster Countermeasure Basic Act that was passed in 2013 states that both national and local government shall partner with civil 
organizations while respecting their autonomy (Okada 2015). Hence, it can be argued that these changes display a certain shift in values, i.e. a push from hierarchical towards egalitarian values

Summarizing the role of voluntarism in managing crises in Japan and Iceland it can be said that that public/voluntary associations have been more involved in the disaster risk reduction phase in Iceland than in Japan - while being important participants in disaster first response and relief in both countries (see Figure 4).

\section{LEARNING}

Records of volcanic eruptions in Iceland and Japan have provided valuable lessons on volcanology and disasters caused by eruption. Official recording begins much later in Iceland than in Japan but fortunately individuals in Iceland did report on the course of events voluntarily. The above-mentioned 1783 eruptions, Asama in Japan and Laki in Iceland, are examples in point. A Japanese record was made by the chief executive of the shogunate, while in Iceland a pastor driven by his own interest and insight kept accurate record of both the eruption and its aftermath. The Japanese record gave, for instance, an overview of casualties and damage reports from different villages, damage to vegetation, and also people's experiences of the eruption. The Icelandic pastor recorded, for instance, on the important lesson about a lethal disease triggered by fluorine-contaminated vegetation, which caused the skin and flesh to rot off the living animals (Lord 2017).

Volcanic eruptions not only provide knowledge about this type of natural hazard and the consequences when it comes in contact with people and/or buildings but give also valuable understanding of human ancestors and early humans which is made possible by the excellent preservation of fossils in volcanic deposits (Sigurdsson 1999). A full-scale excavation survey of Kamohara village was made by researchers in various fields such as humanities, nature and social sciences who are interested in the Asama eruption of Tenmyo in 1783. Thus, academic considerations were made from various angles and shed important light on peoples' lives in the Edo period (Disaster Management, Cabinet Office 2006).

Japan happened to have an unusually few number of major eruptions over the $20^{\text {th }}$ century. It may be one of the explanations of why the number of Japanese volcanologists and university students going into volcano research are down. The eruption of Mount Ontakesan in 2014 shed light on the lack of volcanologists in Japan and was a wakeup call for the government, to strengthen volcano monitoring (Shin'ichirō 2014). Icelandic experts have not published similar concerns.

The eruption of Mount Ontakesan heightened the attention of challenges related to tourism - a concern that the Japanese and Icelandic societies share.

\subsection{Risk awareness and tourism}

In both Iceland and Japan there is an urgent need to raise the volcanic risk awareness among tourists. Mount Fuji has been attracting hikers for centuries. Kuroble village has been a climbing mouth of Mount Fuji since ancient time where travelers gathered from different part of the country and received services from the local people. Hence, this type of tourism has had great economic value for villages such as Kuroble that have access to Mount Fuji. In the 
aftermath of the eruption in 1707 the shogunate actively helped with the reconstruction of Kuroble (Disaster Management, Cabinet Office 2007). Approximately 350-400 thousand visitors have yearly hiked the mountain over the last years. Thereof, a third are foreign tourists. In September 2014, 300 people were hiking Mount Ontakesan when it started to erupt, 57 people were killed, most of whom were tourists. This was the deadliest eruption in the postWWII period. The disaster drew the government's attention to the need of reviewing volcanic disaster guidelines in order to include tourists in evacuation measures. It also motivated work on such measures due to eruption in Mount Fuji (Japan Times Oct 10, 2014). A study on the influence of raised Volcanic Alert Level of six volcanoes in the aftermath of the Mount Ontakesan eruption shows a decrease in tourism that continues for several months after the level has been normalized. Tourism promotions such as accommodation discounts and toll-free roads were shown to have limited effect. Thus, economic countermeasures such as having insurance that covers volcanic activities were encouraged (Torayashiki et al. 2017)

In Iceland more than three hundred thousand people traveled in the highland in 2016. One of the most popular glacier walk tours takes place on Sólheimajökull glacier, part of the Mýdalsjökull ice cap but volcano Katla is partially covered by the ice cap. A survey conducted in the area found a level of complacency among the tourist population (Bird et al. 2009). While all of those surveyed knew that the area was volcanically active, there was a significant lack of awareness of the jökulhlaup hazard and of emergency procedures in place (see Bird et al. 2009 Jóhannesdóttir et al. 2010; Bird el al. 2014). A new study shows that although tourists in summer 2016 were aware of the potential risk due to the unrest in Katla they not only underestimated their personal risk but thought the risk made the experience of hiking near the volcano exclusive and attractive (Heimisdóttir 2017).

\subsection{Country to country learning opportunities}

Although the experience of Japanese society in managing the risk and consequences of volcanic eruptions spans much longer time periods than it does in Iceland and thus provides longer learning process the Icelandic society has been able to develop its own research especially over the last eighty years and share the results with other nations. Scientists of the two nations Iceland and Japan do keep themselves updated about scientific progress in the other country and maintain contact. Cooperation on definite projects is rare however, but several scientists have received education and academic degrees in the other country. A few examples on cooperation in important and interesting projects in disaster prevention and recovery, beneficiary to both countries need also to be mentioned.

\subsubsection{An example of knowledge transfer}

Professor Sigurdur Thórarinsson University of Iceland was a pioneer in the use of tephra layers as marker horizons to establish chronology (Thórarinsson 1981; Lowe 2011). This science has found wide applications in Japan (Suzuki et al 2010), and is an important tool in acquiring historical data for disaster prevention research. Thórarinsson provided also the pioneering monograph (1958), which is for instance the foremost resource about the 1362 jökulhlaup from Öræfajökull (see Roberts and Gudmundsson 2015).

\subsubsection{Volcanic risk assessment and prediction}

Asama Volcano Observatory is situated on the eastern flank of the volcano with an altitude of 1,406 m since 1933. It has thirteen seismic stations twelve of them surrounding the summit 
crater, a tilt recorder in a $30 \mathrm{~m}$ deep vault, electronic distance measurements (EDM) recordings to two points. Leveling campaigns are conducted twice a year and video monitoring is constant. Asama Volcano has a resemblance to the famous Hekla volcano in Iceland and it offers data that are archeologically and volcanologically very special.

\subsubsection{Ash cloud prediction for air traffic}

The ash cloud prediction that caused the Eyjafjallajökull disaster in 2010 is done according to the rules of the international organization ICAO (International Civil Aviation Organization, a specialized agency of the United Nations) and is thus outside the national disaster management systems described in this paper even though the national institutions participate in the work.

Kyoto University started in 2010 a project on airborne in-situ measurements of volcanic ash clouds and plume physics where Icelandic scientists participated until 2015. The project aimed at investigating events like the disaster caused by the Eyjafjallajökull volcanic eruption in 2010 and possible mitigations, (Elíasson 2014a, Elíasson et al. 2016). Overestimations of the size of the volcanic clouds experienced in the North Atlantic is already mentioned in the introduction. The correction method used by Tokyo VAAC to counter such overestimation is explained in Figure 4.

- VAAC Tokyo's 'unique' approach
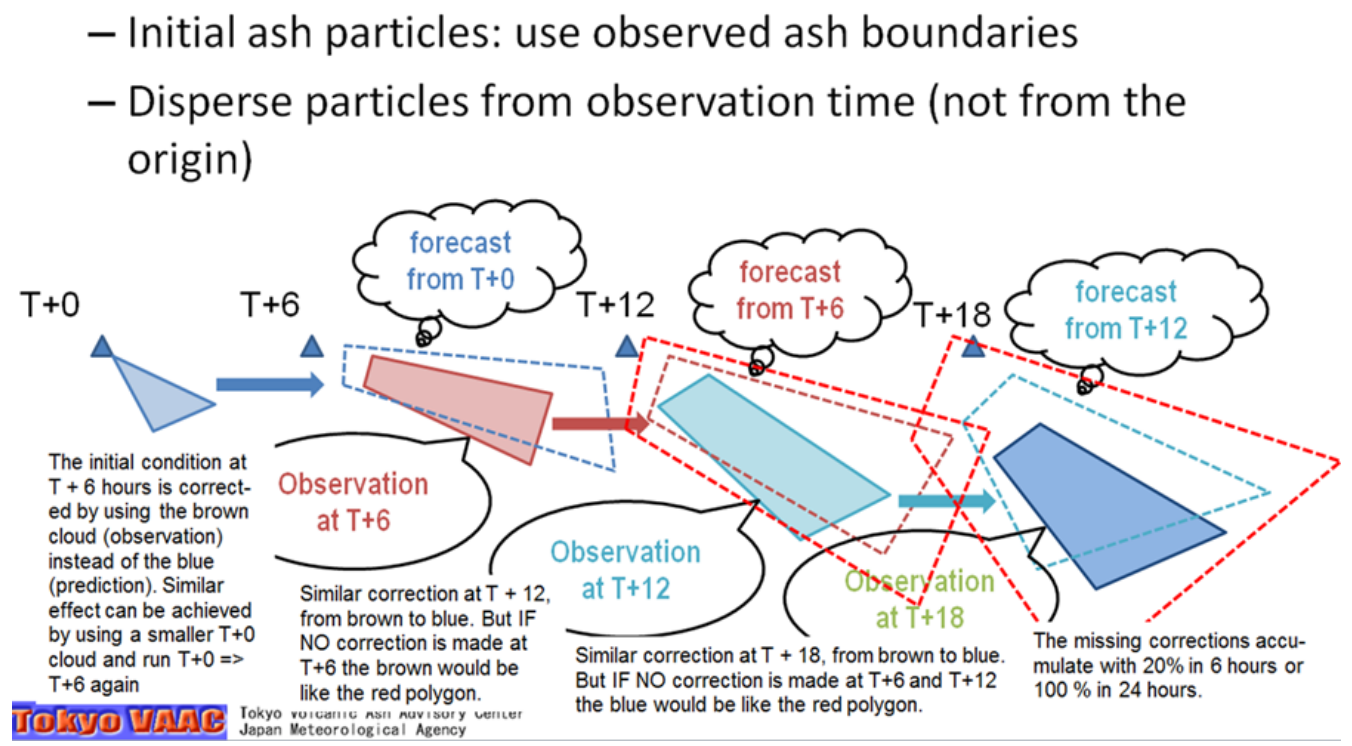

Figure 5. Dotted red curves show the prediction without correction. Other dotted curves show predictions 6 hours ahead from the observations with the same color, they are acquired from satellites. Comparison of the red dotted curves and the observations show how the error accumulates if there is no correction

\section{CONCLUSION}

Volcanic threat challenges are a permanent research object and public concern in Iceland and Japan. This is a natural consequence of the similarities in the geological structures and volcanic activity in these two developed countries. But they are far apart, there are differences in the geological settings, and disaster prevention, relief/recovery follow different cultural 
traditions in the two societies. There are active disaster prevention and recovery operations in all levels of society, governmental, institutional, academic and military and volunteer organizations as well. Following points emerge as conclusions of this study.

$>$ Environment

Level of volcanic threats to the public is historically similar in Iceland and Japan.

* Volcanos create similar challenges for disrupting communications, but the probabilities of similar disruptions are different (e.g. jökulhlaups and flight bans).

* Physical settings of the volcanoes are different, allowing volcanological research to be concentrated in on site volcanological observatories in Japan, while Iceland has to be prepared to volcanic outbreaks in unexpected places,

\section{Disaster Management}

* Structure of the civil protection system is similar, with active leadership from government and institutional participation.

* Hierarchy is the dominant culture in Japan with emphasis on centralized processes and expertise.

* Egalitarianism is the dominant culture in Iceland with emphasis on decentralized processes and voluntarism.

* Japanese information system is the more detailed with shorter response time and quicker updating of online information.

* In Japan the role of Self-Defense Forces in disaster relief missions is extensive and enjoys broad public support in the country

* Iceland has no military and thus relies heavily on volunteer rescue organizations that are highly effective with very short response time and high operational success.

* Voluntarism is on the rise in Japan with formation and legalization of numerous civil society organizations participating in disaster management.

* Voluntary organizations have been the more involved in risk reduction in Iceland while being important in both countries during first responses and relief measures.

\section{$>$ Cooperation possibilities}

- University research and education has brought results that show this form of cooperation to be very valuable in spite of the great distance between the countries.

* Township cooperation and mutual learning has not been developed to any extent, but remains a possiblity that can produce benefits.

* Sharing experience and jointly developing methods to increase safety of tourists offers beneficiary cooperation possibilities. 


\section{ACKNOWLEDGEMENTS}

The authors want to thank the Disaster Prevention Research Institute (DPRI), Kyoto University, for support and encouragement and the Icelandic Research Fund for financial support (Grant number: 163493-051).

\section{REFERENCES}

Bernhardsdóttir, Á. E., and Kristinsson, G. H. (2003) Kúltúrkenning um áfallastjórnun. [In Icelandic. English: Crisis Management and Cultural Theory] Rannsóknir í félagsvísindum IV [Research in Social Sciences IV]. The University Press, Reykjavik.

Bernhardsdóttir, Á. E., and Svedin, L. (2004) Small State Crisis Management: The Icelandic Way. Swedish National Defence College, Stockholm.

Bernhardsdottir, Á. E. (2015a) Crisis-Related Decision-Making and The Influence of Culture on the Behaviour of Decision Makers - Cross-Cultural Behaviour in Crisis Preparedness. Springer International Publishing AG, Cham.

Bernhardsdóttir, Á. E. (2015b) Ethics and Risk Management: The Cultural Perspective. In Svedin, L. ed. Ethics and Risk Management. Information Age Publishing, Inc. Charlotte, NC.

Bird, D., Gísladóttir, G. and Dominey-Howes, D. (2009) Public perception of jökulhlaup hazard and risk in Iceland: implications for community education. International Journal of Management and Decision Making 10(3): 164-175.

Bird, D., Gísladóttir, G. and Dominey-Howes, D. (2014) Tourists visiting Pórsmörk lack knowledge and awareness of Katla and jökulhlaup hazard. Retrieved 8 May 2017. http://citeseerx.ist.psu.edu/viewdoc/download?doi=10.1.1.606.9159\&rep=rep1\&type=pdf

Brown, S. K., Sparks, R. S. J., Mee, K., Vye-Brown, C., Ilyinskaya, E., Jenkins, S., and Loughlin, S. C. (2015) Regional and country profiles of volcanic hazard and risk. Report IV of the GVM/IAVCEI contribution to the Global Assessment Report on Disaster Risk Reduction.

Cabinet Office, Government of Japan (2015) Disaster Management in Japan. March, 2015.

Department of Civil Protection and Emergency Management. Contingency Plan for Katla and Eyjafjallajökull glacier. <Retrieved 8 May 2017> http://www.almannavarnir.is/natturuva/eldgos/vidbunadur/vidbragdsaaetlun-vegna-kotluog-eyjafjallajokuls/katla-og-eyjafjallajokull/

Disaster Management, Cabinet Office (2006) Report on Tenmei Asama eruption in 1783, No. 35 September. <Retrieved 12 October 2016> http://www.bousai.go.jp/kyoiku/kyokun/kyoukunnokeishou/pdf/kouhou035 16-17.pdf

Disaster Management, Cabinet Office (2007) Report on Mount Fujii eruption in 1707, No. 37 January. <Retrieved 8 October 2016> http://www.bousai.go.jp/kyoiku/kyokun/kyoukunnokeishou/pdf/kouhou037 18-19.pdf

Elíasson J., Yoshitani J., and Miki, D. (2016) Measurements of Particle Distribution and Ash Fluxes in the Plume of Sakurajima Volcano with Optical Particle Counter (Special Issue on Integrated Study on Mitigation of Multimodal Disasters Caused by Ejection of Volcanic Products). Journal of disaster research 1881-2473; Fuji Technology Press 2016-02-11, 1 $85-95$. 
Elíasson, J. (2014a) The role of in-situ measurements in of volcanic ash concentrations in preventing economic disasters due to volcanic ash clouds. IDRiM Journal, 4(1), 48-60.

Elíasson, J. (2014b) Katla volcano in Iceland, potential hazards and risk assessment. Natural Science, 6(3) 99-107

Elíasson, J., and Sigbjörnsson, R. (2008) Re-appraisal of tsunami hazard in the North Atlantic Ocean: A case study for Iceland. The 14th World Conference on Earthquake Engineering, Beijing, 12-17 October 2008, 1-6.

Elíasson, J., and Sigbjörnsson, R. (2013). Assessing the Risk of Landslide-Generated Tsunamis, Using Translatory Wave Theory. International Journal of Earthquake Engineering and Hazard Mitigation (IREHM), 1(1), 61-71.

Elíasson, J., Kjaran, S. P., Holm, S. L., Gudmundsson, M. T.. and Larsen, G. (2007). Large hazardous floods as translatory waves. Environmental Modelling \& Software, 22(10), 13921399.

Elíasson, J., Larsen, G., Gudmundsson, M. T., and Sigmundsson, F. (2006). Probabilistic model for eruptions and associated flood events in the Katla caldera, Iceland. Computational Geosciences, 10(2), 179-200.

Encyclopedia Britannica. <Retrieved 10 May 2017> https://www.britannica.com/event/Tokugawa-period.

Gudmundsdóttir, S., Gudlaugsson, Th., and Aðalsteinsson, G. D. (2015) Icelandic National Culture Compared to National Cultures of 25 OECD Member States Using VSM94. Icelandic Review of Politics \& Administration 11(1): 19-32.

Heimisdóttir, T. (2017) The attraction of active volcanoes in tourism. IDRiM 2017 Reykjavik, Iceland. Conference Poster.

Hendrasto M., Rosadi, U., Ohkura T., Triastuty,H., Basuki, A., Loeqman, A., Maryanto, S. et al. Methods for eruption prediction and hazard evaluation at Indonesian volcanoes. Journal of Disaster Research 7, No. 1 (2012): 26-36.

Hofstede, G., and Hofstede, G. J. (2005) Cultures and Organizations: Software of the Mind. New York, NY: McGraw-Hill.

Hermann, C. F. (1963) Some consequences of crisis which limit the viability of organizations. Administration Science Quarterly 8(1): 61-82.

Iceland Catastrophe Insurance. About the ICI. https://www.vidlagatrygging.is/en/about-the$\underline{\text { icil/ }}$

Iguchi, M., Yakiwara, H., Tameguri, T., Hendrasto, M., and Hirabayashi, J. (2008) Mechanism of explosive eruption revealed by geophysical observations at the Sakurajima, Suwanosejima and Semeru volcanoes, Journal of Volcanology and Geothermal Research, 178(1): $1-9$.

Ishihara, K., Hendrasto, M., and Hidayati, S. (2011) Long-term forecasting of volcanic eruption in case of Kelud volcano, Indonesia, Annuals Disaster Prevention Research Institute, Kyoto University, No.54: 209-214.

Japan Times (1991) 18 $8^{\text {th }}$ Century Manual 1991/06/05. <Retrieved October 2016>

Japan Times (2014). $\leq$ Retrieved May 2017>

http://www.japantimes.co.jp/news/2014/10/27/national/ontake-victims-mourned-montheruption-tourism-industry-scrambles-recover/\#.WK1xKjuLSUm 
Jinam, T. A., Kanzawa-Kiriyama, H., and Saitou N. (2015) Human genetic diversity in the Japanese Archipelago dual structure and beyond. Genes \& Genetic Systems. 90(3): 147152.

Jóhannesdóttir, G., and Gísladóttir, G. (2010) People living under threat of volcanic hazard in southern Iceland: vulnerability and risk perception. Natural Hazards and Earth System Sciences, 10: 407-420.

Kamo, K., and Ishihara, K. ( 1989) A preliminary experiment on automated judgement of the stages of eruptive activity using tiltmeter records at Sakurajima, Japan, in IAVCEI Proceedings in Volcanology 1: 585-598.

Karlsson, G. (2010) The eruption that changed Iceland forever. Interview in BBC News Magazine 16 April 2010. <Retrieved June 2017> http://news.bbc.co.uk/2/hi/8624791.stm

Klemetti, E. (2013) Local and Global Impacts of the 1783-84 Laki Eurption in Iceland. $<$ Retrieved June 2017> https://www.wired.com/2013/06/local-and-global-impacts-1793laki-eruption-iceland/

Kuswandarto, H., Hendrasto, M., and Iguchi, M. (2008) Automatic and real-time processing of tilt records for prediction of explosions at Semeru volcano, east Java, Indonesia, Indonesian Journal of Physics, 19(3): 69-74.

Larsen, G., and Gudmundsson, M. T. (2014). Volcanic system: Bárðarbunga system; www.vedur.is/media/jar/Bardarbunga_kafli20140825.pdf

Lord, V. M. The Eruption of Laki: An Icelandic Volcano in 1783. The Ultimate History Project. $<$ Retrieved September 2017> http://ultimatehistoryproject.com/the-eruption-of-laki.html

Loughlin, S. C., Stephen, R., Sparks, J., Sparks, S., Brown, S. K., Jenkins, S. F., and VyeBrown, C. (2015) Global Volcanic Hazards and Risk Cambridge University Press, pp. 408.

Lowe, D. J. (2011) Tephrochronology and its application: a review. Quaternary Geochronology, 6(2):107-153.

Ministry of Justice of Iceland. (2008) Civil Protection Act No. 82 June 2008. <Retrieved May 2017> https://eng.innanrikisraduneyti.is/laws-and-regulations/english/civil-protection/

Neri, A., Cioni, R., Bertagnini, A., Baxter, P. J., Zuccaro, G., Andronico, D, . Barsotti, S., Cole, P. D., Esposti-Ongaro, T., Macedonio, G., Papale, P., Rosi, M., Santacroce, R., and Woo, G. (2008) Developing an Event Tree for probabilistic hazard and risk assessment at Vesuvius. Journal of Volcanology and Geothermal Research, 178(3): 397-415.

NIED 2013, Volcanic Hazard Maps of Japan, Technical Note no 380, National Research Institute of Earth Science and Disaster Prevention (in Japanese), ISSN 0917-057X DVDROM.

Nishimura, T., Iguchi, M., Kawaguchi, R., Surono, Hendrasto, M., and Rosadi, U. (2012) Inflations prior to vulcanian eruptions and gas bursts detected by tilt observations at Semeru Volcano, Indonesia, Bulletin of Volcanology, 74(4): 903-911.

Okada, A. (2015) Civil Society Organizations and Risk Management: The Case of Japan in Svedin, L. (ed) Ethics and Risk Management. Information Age Publishing, Inc. Charlotte, NC.

Óladóttir, B. A., Larsen, G., and Sigmarsson, O. Volume estimates of nine Katla tephra layers ( 1860 BC-870 AD); JÖKULL No. 64, 2014.

Prime Minister of Japan and His Cabinet (2016). Press Conference by Prime Minister Shinzo 
Abe on March 10, 2016. < Retrieved May 2017> http://japan.kantei.go.jp/97 abe/statement /201603/1216516 11003.html

Roberts, M. R., Linde, A. T., Vogfjord, K. S., and Sacks, S. (2011) Forecasting Eruptions of Hekla Volcano, Iceland, using Borehole Strain Observations, EGU2011-14208.

Roberts, M. J., and Gudmundsson, M. T. (2015). Öræfajökull Volcano: Geology and historical floods. In Pagneux, E., Gudmundsson, M. T, Karlsdóttir, S, and Roberts M. J. (Eds.), Volcanogenic floods in Iceland: An assessment of hazards and risks at Öræfajökull and on the Markarfljót outwash plain (17-44). Reykjavík: IMO, IES-UI, NCIP-DCPEM.

Rosenthal, U., and Kouzmin, A. (1993) Globalizing an agenda for contingencies and crisis management: An editorial statement. Journal of Contingencies and Crisis Management 1(1): $1-12$.

Shin'ichirō, S. (2014) Japan's Volcanic Research in Distress: Ontake Eruption Exposes the Dire State of Volcano Surveillance. Nippon.com 12.08. <Retrieved September 2017> http://www.nippon.com/en/currents/d00146/

Sigurdsson, H. (1999) The History of Volocanology in Sigurdsson, H., Houghton, B, Rymer, H, Stix, J, and McNutt, S. (Eds) Encyclopedia of Volcanoes. Academic Press.

Suzuki, T., Koarai, M., and Nakayama, D. (2010) Construction of Japanese tephra database using GIS. Abstracts, International Field Conference on Tephrochronology, Volcanism and Human Activity, Kirishima, Japan (9-17 May). INQUA International Focus Group on Tephrochronology and Volcanism (INTAV), 84.

Suzuki, W., Aoi, S., Sekiguchi, H., and Kunugi, T. (2012) Source rupture process of the 2011 Tohoku-Oki earthquake derived from strong-motion records. Proceedings of the 15 th World Conference on Earthquake Engineering: Lisbon, Portugal. 1.

't Hart, P., Rosenthal U, and Kouzmin, A. (1993) Crisis decision making: the centralization thesis revisited. Administration \& Society 25(1): 12-44

Thompson, M., Ellis, R., and Wildavsky, A. (1990) Cultural Theory. Boulder: Colorado.

Thorarinsson, S. (1981) The application of tephrochronology in Iceland. In Tephra studies (pp. 109-134). Springer, Dordrecht.

Thórdarson, T., and Larsen, G. (2007) Volcanism in Iceland in historical time: Volcano types, eruption styles and eruptive history. Journal of Geodynamics, 43(1): 118-152.

Thorsteinsson, B., and Jónsson, B. (1991) Íslands Saga: til okkar daga [In Icelandic. English: Iceland History: to our days] Sögufélagid, Reykjavík.

Torayashiki, T., Anawat, S., Miwa, K., and Amy, D. (2017) The decrease in tourism and tourism promotion after increased recent volcanic activity in Japan. $8^{\text {th }}$ IDRiM Conference. Reykjavik 23-25 August 2017.

Walker, L. R., and Bellingham, P. (2011) Island Environments in a Changing World. Cambridge University Press, New York.

Weber, K., Elíasson, J., Vogel, A., Fischer, C., Pohl, T., van Haren, G., ... and Dahmann, D. (2012) Airborne in-situ investigations of the Eyjafjallajökull volcanic ash plume on Iceland and over North-western Germany with light aircrafts and optical particle counters. Atmospheric Environment, 48(March): 9-21.

Webster, H. N., Thomson, D. J, Johnson, B. T., Heard, I. P. C., Turnbull, K., Marenco, F., ... and Schumann, U. (2012) Operational prediction of ash concentrations in the distal volcanic 
cloud from the 2010 Eyjafjallajökull eruption. Journal of Geophysical Research: Atmospheres, 117(D20).

World Risk Report 2016; www.WorldRiskReport.org

Yokoo, A., Suzuki, Y. J., and Iguchi, M. (2014) Dual infrasound sources from a vulcanian eruption of Sakurajima volcano inferred from cross-array observation. Seismological Research Letters, 85(6): 1212-1222.

Yoshizaki, T. (2012) The Military's Role in Disaster Relief Operations: A Japanese Perspective. National Institute for Defense Studies (Japan): 14 ${ }^{\text {th }}$ NIDS International Symposium on Security Affairs 2011: Tokyo, Japan. 